\title{
CORRECTION
}

\section{Correction: The clinical significance of oestrogen receptor expression in breast ductal carcinoma in situ}

Islam M. Miligy, Michael S. Toss (D), Sho Shiino, Georgette Oni, Binafsha M. Syed, Hazem Khout, Qing Ting Tan, Andrew R. Green (D) R. Douglas Macmillan, John F. R. Robertson and Emad A. Rakha

British Journal of Cancer (2020) 123:1584; https://doi.org/10.1038/s41416-020-01097-9

Correction to: British Journal of Cancer (2020) https://doi.org/ 10.1038/s41416-020-1023-3, published online 10 August 2020
Since the publication of this paper the authors noticed an error in the name of Dr Qing Ting Tan, which was incorrectly listed as Quing Tan. This has been corrected above. 